\title{
Antioxidant and anti-inflammatory activity of fruit, leaf and branch extracts of Paliurus spina-christi P. Mill.
}

\author{
Ali ŞEN \\ Marmara University, Faculty of Pharmacy, Department of Pharmacognosy, 34668, Haydarpaşa, Üsküdar, İstanbul, Turkey. \\ Correspondence: ali.sen@marmara.edu.tr; alisenfb@hotmail.com; Tel: +90 535938 78 94; ORCID No: 0000-0002-2144-5741
}

Received: 25 January 2018; Revised: 8 February 2018; Accepted: 13 February 2018

\begin{abstract}
In this study, it is aimed to investigate antioxidant and anti-inflammatory activities of ethanol extracts and their $n$-hexane, chloroform, ethyl acetate, and aqueous ethanol fractions of the fruits, leaves, and branches of Paliurus spinachristi P. Mill. (Rhamnaceae). The antioxidant activity of the extracts was tested by DPPH and ABTS methods and the results were expressed as $\mathrm{IC}_{50}$ values. The total phenolic content was determined by Folin-Ciocalteu method and the results were expressed as $\mathrm{mg}$ of gallic acid equivalent per $\mathrm{g}$ dry extract. Anti-inflammatory activity of extracts were evaluated against 5lipoxygenase enzyme. In particular, all extracts obtained from branches of $P$. spina-christi, except hexane extract, showed strong antioxidant activity against DPPH and ABTS radicals. Ethyl acetate and ethanol extracts of branches of $P$. spina-christi showed the highest antioxidant activity in DPPH and ABTS assays with $\mathrm{IC}_{50}$ values of 15.54 and $22.06 \mu \mathrm{g} / \mathrm{ml}$, respectively. Also, the highest total phenol content was found in the ethyl acetate extract of branches of $P$. spina-christi (286.6 mg/g). Ethyl acetate and ethanol extracts of leaves of $P$. spina-christi with $\mathrm{IC}_{50}$ values of 66.28 and $76.75 \mu \mathrm{g} / \mathrm{ml}$ were found to have the best anti-inflammatory activity in the lipoxygenase (LOX) inhibition assay used to evaluate anti-inflammatory activities of extracts. These results demonstrate that ethanol and ethyl acetate extracts from branches and leaves of Paliurus spina-christi have significant antioxidant and anti-inflammatory activity. Also, these results confirm the folk use of the plant as an antiinflammatory medicine.
\end{abstract}

KEYWORDS: Paliurus spina-christi P. Mill.; Rhamnaceae; Antioxidant activity; Anti-inflammatory activity.

\section{INTRODUCTION}

The genus Paliurus, belongs to the Rhamnaceae family, is represented by one species in the flora of Turkey, Paliurus spina-christi. It is spiny shrub, growing two to four meters tall, with arching branches [1]. This species is known by local names such as "Karaçalı”, "draga dikeni”, “öküz gözü”, “çaltı”, "ilme”, "çaltı dikeni”, "sarı çalı”, "sarı diken", "çalı bakıldağı", "çantı dikeni" [2-7] and is used as diuretic, antirheumatic, hypocholesterolemic, tonic, expectorant for children, anti-inflammatory, antitussive, tonic as well as in the treatment of cough, diarrhea, chronic obstructive pulmonary disease, abdominal pain, stomach pain, nausea, diabetes, nephralgia, kidney stones, sore throat, bronchitis, atherosclerosis, haemorrhoid, urinary tract infection in traditional Turkish herbal medicine [2-11]. It have also been reported in scientific studies that different extracts of this species have antimicrobial, hypolipidemic, antioxidant, and antigenotoxic activities [11-15]. The leaves, flowers, and fruits of Paliurus spina-christi contain flavonoids (quercetin hexoside, quercetin, naringenin- $\mathrm{C}$-diglycoside, quercetin 3-Orhamnoglucoside 7-O-rhamnoside, quercetin-3-O-triglycoside, quercetin-3-O-a-rhamnosyl $(1 \rightarrow 6)-\beta$-galactoside, quercetin-3-O- $a$-rhamnosyl $(1 \rightarrow 6)-\beta$-galactoside-7-O- $\alpha$-rhamnoside, hyperoside, quercetin-3-O-[- $\beta$-xylosyl $(1 \rightarrow 2)$ $a$-rhamnozil $(1 \rightarrow 6)]$ - $\beta$-glucoside, quercetin-3-rutinoside-7-rhamnoside, isoquercitrin, rutin, kaempferol-3glycoside), tannins (epigallocatechol, gallocatechol, catechol, gallocatechin, gallocatechin, $(+)$ and $(-)$ catechin, epigallocatechin, catechin hydrate, proanthocyanidin B dimer), phenolic acids (5-caffeoyl quinic acid 5-pcoumaroylquinic acid), coumarins, amino acids, fatty acids, and alkaloids [9,11,12,15-18].

How to cite this article: Şen A. Antioxidant and anti-inflammatory activity of fruit, leaf and branch extracts of Paliurus spina-christi P. Mill. Marmara Pharm J. 2018; 22 (2): 328-333. 
There are only three studies on antioxidant activity of this species in the literature $[9,13,14]$. However, antioxidant activities of fruits, leaves and branches of Paliurus spina-christi were separately determined for first time in this study. In addition to, the antioxidant activities of the extracts obtained by using different solvents from the different parts of the plant were first evaluated comparatively in this study. Also, no literature could be found in respect of the anti-inflammatory activity of Paliurus spina-christi. The antioxidant and anti-inflammatory effects of various solvent extracts from different parts of the plant were therefore investigated.

\section{RESULTS}

Almost all extracts except for the hexane extracts were found to have a significant antioxidant activity. PSBEA showed the highest antioxidant activity with $\mathrm{IC}_{50}$ value of $15.54 \mu \mathrm{g} / \mathrm{ml}$, while PSFH showed the lowest antioxidant activity with $\mathrm{IC}_{50}$ value of $2174 \mu \mathrm{g} / \mathrm{ml}$ in DPPH assay. In the ABTS experiment, PSBE exhibited the highest antioxidant activity with $\mathrm{IC}_{50}$ value of $22.06 \mu \mathrm{g} / \mathrm{ml}$, while PSFH exhibited the lowest antioxidant activity with $\mathrm{IC}_{50}$ value of $851.0 \mu \mathrm{g} / \mathrm{ml}$. In both ABTS and DPPH assays, all extracts showed low antioxidant activity when compared to standards. Among all the tested extracts the highest amounts of total phenolic were found in the PSBEA $(286.6 \mathrm{mg} / \mathrm{g})$. The total phenol contents of other extracts ranged between 2.44 and $216.2 \mathrm{mg}$ GAE per $\mathrm{g}$ extract (Table 1). PSLE and PSLEA inhibited lipoxygenase activity by $100 \%$ at a concentration of $156 \mu \mathrm{g} / \mathrm{ml}$. PSLE and PSLEA showed strong anti-lipoxygenase activity with $\mathrm{IC}_{50}$ values of $76.75 \pm 1.99$ and $66.28 \pm 0.73 \mu \mathrm{g} / \mathrm{ml}$, respectively ( $\mathrm{IC}_{50}$ for indomethacin: $18.05 \pm 0.95 \mu \mathrm{g} / \mathrm{ml}$ ). Also, PSFH extract at a concentration of $156 \mu \mathrm{g} / \mathrm{ml}$ showed lowest anti-lipoxygenase activity with inhibition rate of $24.36 \%$ (Figure 1 ).

Table 3. Antioxidant activities and total phenolic contents of various extracts obtained from different parts of Paliurus spina-christi.

\begin{tabular}{|c|c|c|c|c|}
\hline $\begin{array}{l}\text { Extracts } \% / \\
\text { Standards }\end{array}$ & $\begin{array}{c}\text { Yield } \\
(\%)\end{array}$ & $\begin{array}{c}\text { DPPH activity } \\
\text { IC }_{50}\left(\mu \mathrm{gml}^{-1}\right)\end{array}$ & $\begin{array}{c}\text { ABTS activity } \\
\text { IC }_{50}\left(\mu \text { gml }^{-1}\right)\end{array}$ & $\begin{array}{c}\text { TPC } \\
\text { (mg GAE/g extract)** }^{*} \text {. }\end{array}$ \\
\hline PSLE & 7.03 & $50.88 \pm 0.99 \mathrm{~b}, \mathrm{c}, \mathrm{d}$ & $46.73 \pm 0.72 \mathrm{e}$ & $106.9 \pm 0.65 \mathrm{~g}$ \\
\hline PSLH & 2.44 & $1153 \pm 35.36^{h}$ & $313.4 \pm 0.64^{\mathrm{h}}$ & $3.83 \pm 0.42^{a}$ \\
\hline PSLC & 1.26 & $72.60 \pm 1.81^{\mathrm{c}, \mathrm{d}, \mathrm{e}}$ & $46.21 \pm 1.10 \mathrm{e}$ & $76.38 \pm 0.68 \mathrm{e}$ \\
\hline PSLEA & 0.49 & $20.19 \pm 0.05^{b}$ & $26.19 \pm 0.79 b, c$ & $210.0 \pm 3.98 j$ \\
\hline PSLAE & 2.45 & $31.11 \pm 0.01^{b, c}$ & $41.83 \pm 0.92^{\mathrm{d}}$ & $149.1 \pm 3.66^{h}$ \\
\hline PSBE & 6.75 & $18.32 \pm 0.11^{b}$ & $22.06 \pm 0.17 \mathrm{~b}$ & $216.2 \pm 2.92 \mathrm{j}$ \\
\hline PSBH & 0.76 & $272.1 \pm 0.42 \mathrm{~g}$ & $92.55 \pm 0.76^{f}$ & $6.26 \pm 0.16^{a}$ \\
\hline PSBC & 0.86 & $27.00 \pm 0.65^{b, c}$ & $27.18 \pm 0.80^{c}$ & $147.8 \pm 0.80^{\mathrm{h}}$ \\
\hline PSBEA & 1.30 & $15.54 \pm 0.02^{b}$ & $23.40 \pm 0.47 \mathrm{~b}, \mathrm{c}$ & $286.6 \pm 0.90^{k}$ \\
\hline PSBAE & 3.17 & $20.36 \pm 0.04^{b}$ & $27.66 \pm 1.35^{c}$ & $194.4 \pm 2.28^{\mathrm{i}}$ \\
\hline PSFE & 4.97 & $96.19 \pm 0.98^{\mathrm{d}, \mathrm{e}}$ & $47.76 \pm 0.94 \mathrm{e}$ & $61.24 \pm 2.28^{\mathrm{d}}$ \\
\hline PSFH & 3.12 & $2174 \pm 27.58^{i}$ & $851.0 \pm 1.27^{\mathrm{i}}$ & $2.44 \pm 0.27 \mathrm{a}$ \\
\hline PSFC & 0.48 & $98.21 \pm 0.50 \mathrm{e}$ & $40.47 \pm 1.05^{\mathrm{d}}$ & $85.13 \pm 1.27^{f}$ \\
\hline PSFEA & 0.20 & $283.5 \pm 2.05 \mathrm{~g}$ & $108.8 \pm 0.92 \mathrm{~g}$ & $17.81 \pm 0.27 b$ \\
\hline PSFAE & 1.37 & $189.6 \pm 1.41^{\mathrm{f}}$ & $112.0 \pm 2.55 \mathrm{~g}$ & $36.49 \pm 0.90^{c}$ \\
\hline Ascorbic acid & & $2.5 \pm 0.24^{a}$ & & \\
\hline Trolox & & & $3.17 \pm 0.03 \mathrm{a}$ & \\
\hline
\end{tabular}

\footnotetext{
* Abbreviations: PSLE, PSLH, PSLC, PSLEA, PSLAE show the ethanol extracts and its $n$-hexane, chloroform, ethyl acetate, and aqueous ethanol fractions of the leaves of Paliurus spina-christi, respectively. PSBE, PSBH, PSBC, PSBEA, PSBAE show the ethanol extracts and its $n$-hexane, chloroform, ethyl acetate, and aqueous ethanol fractions of the branches of Paliurus spina-christi, respectively. PSFE, PSFH, PSFC, PSFEA, PSFAE show the ethanol extracts and its $n$-hexane, chloroform, ethyl acetate, and aqueous ethanol fractions of the fruits of Paliurus spina-christi, respectively. ${ }^{* *}$ Results were expressed as gallic acid equivalent (GAE). Each value in the table is represented as mean $\pm S D(n=3)$. Different letter superscripts in the same column indicate significant differences $(P<0.05)$.
} 


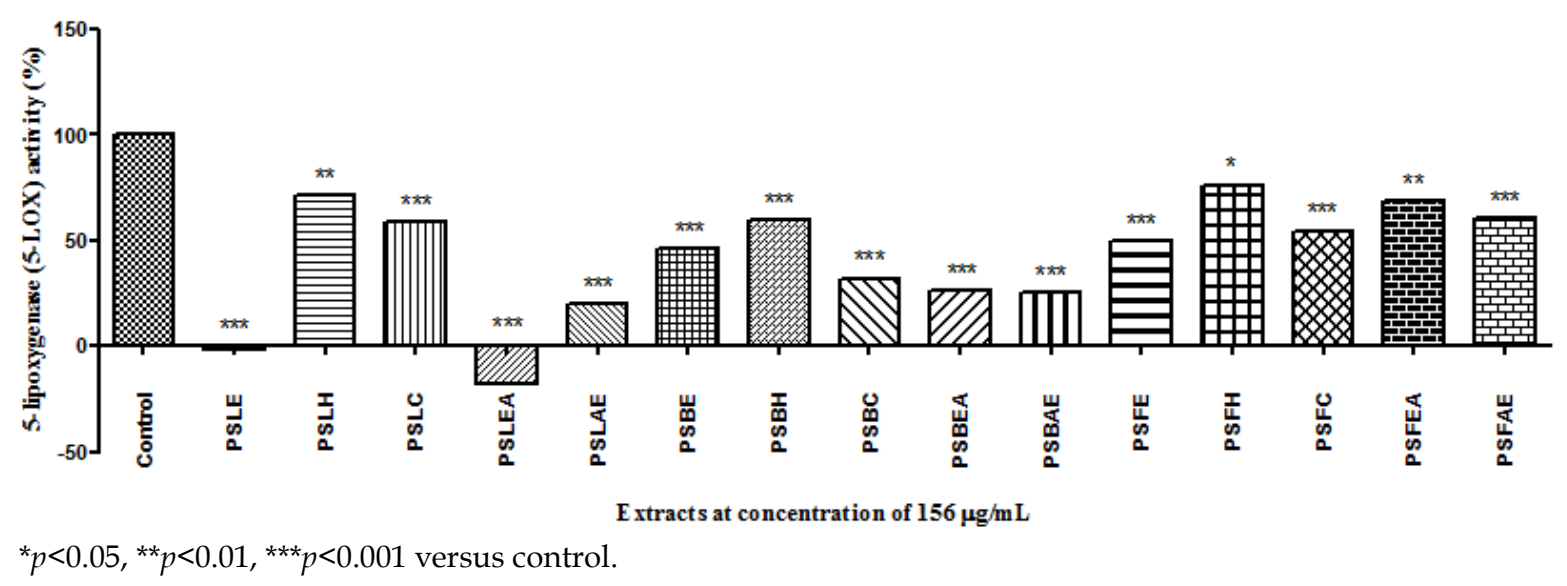

Figure 1. Anti-inflammatory activity of Paliurus spina-christi extracts.

\section{DISCUSSION}

In the present study, the antioxidant and anti-inflammatory activities of ethanol extracts and their $n$-hexane, chloroform, ethyl acetate, and aqueous ethanol fractions of the fruits, leaves, and branches of Paliurus spina-christi were evaluated. PSLEA, PSBE, PSBEA, PSBAE against DPPH radical and PSLEA, PSBE, PSBC, PSBAE against ABTS radical showed significant antioxidant activity.

Only three studies have been found in the literature on the antioxidant activity of Paliurus spina-christi. In one of these studies, Jukic et al. (2012) reported methanol, chloroform, ethyl acetate extracts of Paliurus spina-christi flos have antioxidant activity against DPPH radical with $\mathrm{IC}_{50}$ values of 1.75, 4.15 and $4.35 \mathrm{mg} / \mathrm{ml}$, respectively. Also, total phenol contents of methanol, chloroform, ethyl acetate extracts of Paliurus spina-christi were found to be $64.85,10.27,5.99 \mathrm{mg} / \mathrm{g}$, respectively [13]. In another study, it was demonstrated that methanol extracts of flower and branches with leaf of Paliurus spina-christii have antioxidant activity against DPPH radical with $\mathrm{IC}_{50}$ values of 0.211 and $0.302 \mathrm{mg} / \mathrm{ml}$, respectively. In the same study, it was reported that total phenol contents of methanol extracts of flower and branches with leaf of plant was 91.20 and $75.50 \mathrm{mg} / \mathrm{g}$, respectively [14]. Kayalar et al. (2016) have showed that methanol extract of Paliurus spina-christi fruits has DPPH radical scavenging activity with $\mathrm{IC}_{50}$ value of $0.062 \mathrm{mg} / \mathrm{ml}$. Also, total phenolic content of methanol extract of the plant was found to be 109.54 $\mathrm{mg} / \mathrm{g}$ [9]. When we compared these results with our current study in terms of ethanol or methanol extracts of the plant, generally there were better results in this study, except for the studies of Kayalar et al (2016). However, the antioxidant activities and total phenol contents of the extracts obtained from the leaves and branches of the plant were better than those obtained in these studies. In particular, ethanol and ethyl acetate extracts obtained from branches and leaves of the plant have been found to have significant antioxidant activity and high amount of phenolic contents. Phenolic compounds present in plants are known to be powerful antioxidants [19]. Also, in the phytochemical studies on different parts of the plant, it have been reported that this species contained phenolic compounds such as flavonoids and tannins intensively. Therefore, the high antioxidant activity of these extracts might be resulting from the high total phenolic contents of them.

No studies on the anti-inflammatory activity of the plant have been reported in the literature. However, some parts of the plant have been used by the people for anti-inflammatory purposes. In our current study, it was found that especially the PSLE and PSLEA had significant anti-inflammatory activity. These results confirm ethnobotanical use of the plant. Also, flavonoids are known as compounds with an important anti-inflammatory activity [20]. Therefore, the reason for the good anti-inflammatory activity of PSLE and PSLEA may be due to the presence of high phenolic compounds.

\section{CONCLUSION}

These findings suggest that ethanol and ethyl acetate extracts from leaves and branches of Paliurus spinachristii are good sources of antioxidant and anti-inflammatory agents. Also, these results support traditional use of the plant for anti-inflammatory purposes. 


\section{MATERIALS AND METHODS}

\subsection{Plant material}

Plant samples were collected from the Çatalca district of İstanbul province of Turkey in 2009 and identified by Dr. Ahmet Doğan, a botanist of the Faculty of Pharmacy, University of Marmara. Voucher specimens were deposited in the Herbarium of the Faculty of Pharmacy, Marmara University (MARE No: 19205).

\subsection{Extraction}

About $15 \mathrm{~g}$ of each dried and ground the fruits (PSFE), leaves (PSLE), and branches of Paliurus spina-christi (PSBE) were extracted with $6 \times 200 \mathrm{ml} \mathrm{EtOH}$, using an ultrasonic bath. After filtration and evaporation, the ethanol extracts was dissolved in $30 \mathrm{ml} 60 \%$ aqueous ethanol, and subjected to solvent-solvent partition between $n$ hexane $(5 \times 50 \mathrm{ml})$, chloroform $(3 \times 50 \mathrm{ml})$, and ethyl acetate extract $(2 \times 50 \mathrm{ml})$. The $n$-hexane, chloroform, ethyl acetate extract and aqueous ethanol extracts of Paliurus spina-christi fruits obtained by this method were coded as PSFH, PSFC, PSFEA and PSFAE, respectively. The $n$-hexane, chloroform, ethyl acetate extract and aqueous ethanol extracts of Paliurus spina-christi leaves obtained by this method were coded as PSLH, PSLC, PSLEA and PSLAE, respectively. The $n$-hexane, chloroform, ethyl acetate extract and aqueous ethanol extracts of Paliurus spina-christi branches obtained by this method were coded as PSBH, PSBC, PSBEA and PSBAE, respectively. Extraction yields have been summarized in Table 1. All extracts were stored under refrigeration for further analysis.

\subsection{Antioxidant activity}

\subsubsection{DPPH radical scavenging activity}

Free radical scavenging capacity of Paliurus spina-christi extracts were evaluated according to the previously reported procedure using the stable DPPH [21]. Briefly, $10 \mu 1$ of extracts in DMSO at different concentrations (250$0.048 \mu \mathrm{g} / \mathrm{ml})$ were added to $190 \mu \mathrm{l}$ methanol solution of DPPH $(0.1 \mathrm{mM})$ in a well of 96 -well plate. The mixture was shaken vigorously and allowed to stand in the dark at room temperature for $30 \mathrm{~min}$. Absorbance readings were taken at $517 \mathrm{~nm}$. The percent radical scavenging activity of extracts and standard against DPPH were calculated according to the following:

DPPH radical-scavenging activity $(\%)=\left[\left(\mathrm{A}_{0}-\mathrm{A}_{1}\right) / \mathrm{A}_{0}\right] \times 100$

where $\mathrm{A}_{0}$ is the absorbance of the control (containing all reagents except the test compounds), and $\mathrm{A}_{1}$ is the absorbance of the extracts/standard. Extract concentration providing $50 \%$ inhibition $\left(\mathrm{IC}_{50}\right)$ was calculated from the graph plotting inhibition percentage against extracts concentration. Tests were carried out in triplicate. Ascorbic acid was used as positive control.

\subsubsection{ABTS radical-scavenging activity}

Free radical scavenging capacity of Paliurus spina-christi extracts were evaluated according to the previously reported procedure [21]. ABTS radical cations were prepared by mixing equal volume of ABTS $\left(7 \mathrm{mM}\right.$ in $\left.\mathrm{H}_{2} \mathrm{O}\right)$ and potassium persulfate $\left(4.9 \mathrm{mM}\right.$ in $\left.\mathrm{H}_{2} \mathrm{O}\right)$, allowing them to react for 12-16 h at room temperature in the dark. Then, ABTS radical solution was diluted with $96 \%$ ethanol to an absorbance of about 0.7 at $734 \mathrm{~nm} .10 \mu 1$ of extracts in DMSO at different concentrations $(250-0.048 \mu \mathrm{g} / \mathrm{mL})$ were added to $190 \mu \mathrm{l}$ of ABTS radical solution in a well of 96-well plate. The mixture was shaken vigorously and allowed to stand in the dark at room temperature for 30 min. Absorbance readings were taken at $734 \mathrm{~nm}$. The percent radical scavenging activity of extracts and standard against ABTS were calculated according to the following:

ABTS radical-scavenging activity $(\%)=\left[\left(\mathrm{A}_{0}-\mathrm{A}_{1}\right) / \mathrm{A}_{0}\right] \times 100$

where $\mathrm{A}_{0}$ is the absorbance of the control (containing all reagents except the test compounds), and $\mathrm{A}_{1}$ is the absorbance of the extracts/standard. Extract concentration providing 50\% inhibition (IC 50 ) was calculated from the graph plotting inhibition percentage against extracts concentration. Tests were carried out in triplicate. Trolox was used as positive control. 


\subsection{Determination of Total Phenolic Contents (TPC)}

Total phenolic contents of Paliurus spina-christi extracts were measured using Folin-Ciocalteau reagent [22]. The assay was adapted to the 96 well microplate format. $10 \mu \mathrm{l}$ of extracts in various concentrations (151.52-18.94 $\mu \mathrm{g} / \mathrm{ml}$ ) were mixed with $20 \mu \mathrm{l}$ Folin-Ciocalteu reagent (Sigma), $200 \mu \mathrm{l}$ of $\mathrm{H}_{2} \mathrm{O}$, and $100 \mu \mathrm{l}$ of $15 \% \mathrm{Na}_{2} \mathrm{CO}_{3}$, and the absorbance was measured at $765 \mathrm{~nm}$ after $2 \mathrm{~h}$ incubation at room temperature. Gallic acid was used as a standard and the total phenolics were expressed as mg GAE/g extract.

\subsection{In vitro anti-inflammatory activity}

The anti-inflammatory activity was evaluated according to the method described by Phosrithong et al [23]. An aliquot of $500 \mu \mathrm{l}$ at different concentrations of Paliurus spina-christi extracts was added to $250 \mu \mathrm{l}$ of $0.1 \mathrm{M}$ borate buffer $\mathrm{pH}$ 9.0, followed by addition of $250 \mu \mathrm{l}$ of type $\mathrm{V}$ soybean lipoxygenase solution in buffer $(20.000 \mathrm{U} / \mathrm{ml})$. After the mixture was incubated at $25^{\circ} \mathrm{C}$ for $5 \mathrm{~min}, 1000 \mu \mathrm{l}$ of $0.6 \mathrm{mM}$ linoleic acid solution was added, mixed well and the change in absorbance at $234 \mathrm{~nm}$ was recorded for $6 \mathrm{~min}$. Indomethacin was used as a reference standard. The percent inhibition was calculated from the following equation:

$\%$ inhibition $=\left[\left(\mathrm{A}_{\text {control }}-\mathrm{A}_{\text {sample }}\right) / \mathrm{Ac}_{\text {ontrol }}\right] \times 100$

A dose-response curve was plotted to determine the $\mathrm{IC}_{50}$ values. $\mathrm{IC}_{50}$ is defined as the concentration sufficient to obtain $50 \%$ of a maximum anti-inflammatory activity. All tests and analyses were performed in triplicates.

\subsection{Statistical analysis}

The data were given as means \pm standard deviations and analysed by one-way analysis of variance (ANOVA) followed by the Tukey's multiple comparison tests using GraphPad Prism 5. Differences between means at $\mathrm{p}<0.05, \mathrm{p}<0.01, \mathrm{p}<0.001$ levels were considered significant.

Acknowledgements: The author would like to thank Prof. Leyla Bitiş and Assist.Prof. Ahmet Doğan for their help in collection and identification of the plant material.

Author contributions: Concept - A.Ş; Design - A.Ş; Resource - A.Ş; Materials - A.Ş; Data Collection \&/or Processing - A.Ş; Analysis \&/or Interpretation - A.Ş; Literature Search - A.Ş; Writing - A.Ş; Critical Reviews - A.Ş.

Conflict of interest: The author declared no conflict of interest.

\section{REFERENCES}

[1] Davis PH, Flora of Turkey and East Aegean Island, Vol. 2. Edinburgh University Press, Edinburgh, UK 1967.

[2] Bulut G. Folk medicinal plants of Silivri (İstanbul, Turkey). Marmara Pharm J. 2011; 15: 25-29.

[3] Kargığlu M, Cenkci S, Serteser A, Evliyaoğlu N, Konuk M, Kök MŞ, Bağcı Y. An Ethnobotanical Survey of Inner-West Anatolia, Turkey. Hum Ecol. 2008; 36: 763-777.

[4] Kargioğlu M, Cenkci S, Serteser A, Konuk M, Vural G. Traditional Uses of Wild Plants in the Middle Aegean Region of Turkey. Hum Ecol. 2010; 38: 429-450.

[5] Sargin SA, Akçicek E, Selvi S. An ethnobotanical study of medicinal plants used by the local people of Alaşehir (Manisa) in Turkey. J Ethnopharm. 2013; 150: 860-874.

[6] Uzun M, Kaya A. Ethnobotanical research of medicinal plants in Mihalgazi (Eskişehir, Turkey). Pharm Biol. 2016; 54(12): 2922-2932.

[7] Tuzlacı E, Tolon E. Turkish folk medicinal plants, part III: Şile (Istanbul). Fitoterapia. 2000; 71: 673-685.

[8] Öz Aydın, S, Dirmenci T, Tümen G, Başer KHC. Plants used as analgesic in the folk medicine of Turkey. ICEB 2005. 2006; 167-171.

[9] Kayalar E, Küçük S, Göğer F. Determination of antioxidant activity and phenolic profile of Paliurus spina-christi P. Mill. Clin Exp Pharmacol. 2016; 6: 2 (Suppl). 
[10] Sezik E, Zor M, Yeşilada E. Traditional Medicine in Turkey II. Folk Medicine in Kastamonu. Int J Pharmacognosy. 1992; 30: 233-239.

[11] Zor M, Aydın S, Güner N, Başaran N, Başaran AA. Antigenotoxic properties of Paliurus spina-christi Mill fruits and their active compounds. BMC Complement Altern Med. 2017; 17: 1-10.

[12] Kemertelidze EP, Dalakishvili TsM, Gusakova SD, Shalashvili KG, Khatiashvili NS, Bitadze MA, Gogilashvili LM, Bereznyakova AI. Chemical composition and pharmacological activity of the fruits of Paliurus spina-christi Mill. Pharm Chem J. 1999; 33(11): 591-594.

[13] Jukic M, Burcul F, Carev I, Politeo O, Milos M. Screening for acetylcholinesterase inhibition and antioxidant activity of selected plants from Croatia. Nat Prod Res. 2012; 26(18), 1703-1707.

[14] Kirca A, Arslan E. Antioxidant capacity and total phenolic content of selected plants from Turkey. Int J Food Sci Technol. 2008; 43: 2038-2046.

[15] Brantner A, Males Z, Pepeljnjak S, Antolic A. Antimicrobial activity of Paliurus spina-christi Mill. (Christ's thorn). J Ethnopharmacol. 1996; 52: 119-122.

[16] Kuštrak D, Željan M, Brantner A, Pitarević I. Flavonoids of the leaves of Christ's thorn (Paliurus spina-christi Mill.). Acta pharm Iugoslavica. 1990; 40(4): 551-554.

[17] Dalakishvili TsM, Zurabishvili TS, Kemertelidze EP. Phytochemical investigation of Paliurus spina-christi. Khim Prir Soedin. 1986; 5: 639 .

[18] Brantner AH, Males Z. Quality assessment of Paliurus spina-christi extracts. J Ethnopharmacol. 1999; 66: 175-179.

[19] Kapewangolo P, Omolo JJ, Bruwer R, Fonteh P, Meyer D. Antioxidant and anti-inflammatory activity of Ocimum labiatum extract and isolated labdane diterpenoid. J Inflamm. 2015; 12: 1-13.

[20] Serafini M, Peluso I, Raguzzini A. Flavonoids as anti-inflammatory agents. Proc Nutr Soc. 2010; 69(3): 273-278.

[21] Zou Y, Chang SK, Gu Y, Qian SY. Antioxidant activity and phenolic compositions of lentil (Lens culinaris var. morton) extract and its fractions). J Agric Food Chem. 2011; 59(6): 2268-2276.

[22] Gao X, Ohlander M, Jeppsson N, Björk L, Trajkovski V. Changes in antioxidant effects and their relationship to phytonutrients in fruits of Sea Buckthorn (Hippophae rhamnoides L.) during maturation. J Agric Food Chem. 2000; 48: 14851490.

[23] Phosrithong N, Nuchtavorn N. Antioxidant and anti-inflammatory activites of Clerodendrum leaf extracts collected in Thailand. Eur J Integr Med. 2016; 8: 281-285.

This is an open access article which is publicly available on our journal's website under Institutional Repository at http://dspace.marmara.edu.tr. 